\title{
TREATMENT OF HUMAN SCABIES WITH ORAL IVERMECTIN
}

\author{
Ismael A. CONTI DÍAZ(1) \& Jorge AMARO(2)
}

\begin{abstract}
SUMMARY
Thirty-eight patients with scabies ( 21 males and 17 females) received oral ivermectin in two doses of $200 \mu \mathrm{g} / \mathrm{kg}$ at 7 days interval. Excellent results were achieved in 29 cases $(76.34 \%)$, improvement in $6(15.78 \%)$ and poor responses in 3 (7.88\%). Tolerance was satisfactory-excellent in 32 patients $(84.2 \%)$. The effectiveness and safety of the drug described in previous studies are confirmed by the present results.
\end{abstract}

KEYWORDS: Ivermectin; Scabies; Treatment.

\section{INTRODUCTION}

Human scabies (h. s.) represents a great public health problem in many countries around the world due to its very high prevalence. Approximately 300 millions people would be infected ${ }^{8}$.

After several decades without h. s. cases in Uruguay, since the beginning of the seventies an increasing number of patients are being observed.

Lindane $1 \%$ has been the most commonly used scabicide. It is a very effective drug but if misused, serious toxic neurologic effects may appear. Topical pyrethroids are effective and safe but usually multiple applications are needed.

For these reasons it becomes important to assay new drugs able to act against Sarcoptes scabiei.

Ivermectin is a macrocyclic lactone produced by the soil actinomycete, Streptomyces avermitilis, devoid of antibacterial activity that acts strongly against a wide variety of insects, nematodes and acarine parasites of animals and humans ${ }^{5}$. It is considered to be the main drug for treatment of the filarial worm Onchocerca volvulu ${ }^{5,8}$.

While in Veterinary Medicine there exists a well known experience on efficacy of the drug on several ectoparasitoses, more information is necessary to affirm its true therapeutic activity in human ectoparasitoses.

The purpose of this paper is to communicate our experience with oral ivermectin in h. s. cases.

\section{MATERIALS AND METHODS}

A personal sheet containing the following items was used:

a) Personal data (name, age, sex, weight, relevant associated diseases, address, etc).

b) General characteristics of scabiotic clinical symptoms (papules, vesicles, burrows, nodules, itching) classifying each of them in: absent (0), mild (1), moderate (2), and severe (3), at consultation, after the second week of treatment and two weeks later.

c) Parasitological examination, searching for mites or eggs.

d) Drug tolerance.

e) Results. Results were classified as satisfactory when no pruritus and dermatological signs of scabies were present at the end of the period, unsatisfactory and improvement when disappearance of those signs was only partially obtained.

Diagnosis of disease was made through clinical symptoms, epidemiological records and parasitological examination.

Because of the apparently known safety of ivermectin in humans treated with parasitic diseases, no complementary laboratory exams were ordered.

Ivermectin provided by Laboratorios Dispert S.A. (Montevideo, Uruguay) was prepared as a $0.08 \%$ solution and administered by oral route with fruit juice.

Patients received 2 doses of $200 \mu \mathrm{g} / \mathrm{kg}(1 \mathrm{~mL}$ per each $4 \mathrm{~kg})$ separated by a week interval. They were asked to come back to consultation one week after the second dose and again two weeks later to assess evolution

(1) Dermatologist. Ex Professor and Chairman Department of Parasitology, School of Medicine, Montevideo, Uruguay.

(2) Laboratorios Dispert $S$. A. Veterinary Department Advisor.

Correspondence to: I. A. Conti Díaz, Ayacucho 3314, Montevideo, Uruguay. 
and final results. No other medications were prescribed after the initial visit. Also strict hygienic measures like frequent changes of clothes, boiling of underwear, bed linen, etc. were advised. Participation was voluntary.

\section{RESULTS}

Forty three patients, 23 men and 20 women, ranging from 5 to 85 years of age (Fig.1) were studied. Twenty one of them had moderate scabies, 19 mild symptoms and 5 severe disease. Three of them suffered psoriasis, 1 porokeratosis of Mibelli and another one was seropositive for HIV.

Five patients were excluded because of no return in time for examination in one case and for unordered concomitant use of topical insecticides in other 4 .

Satisfactory result was obtained in 29 patients $(76.34 \%)$ with disappearance of symptomatology 4 weeks after the first dose of ivermectin. Only improvement was noted in 6 patients (15.78\%) being necessary the topical application of acaricides for obtaining cure in 3 of them; in the other 3 , itching persisted together with worsening of psoriasis or porokeratosis according to the case and eczematization of lesions, respectively. In three other cases results were unsatisfactory, $7.88 \%$ (Fig. 2); one of them, seropositive for HIV, had a severe form of scabies and cured after a new dose of ivermectin plus topical pyrethroids. Another one did not observe the hygienic measures recommended, making the possibility of reinfection.

Among the 5 severe forms observed, one had only improvement, another one cured perfectly well and the remaining 3 showed an unfavorable outcome.

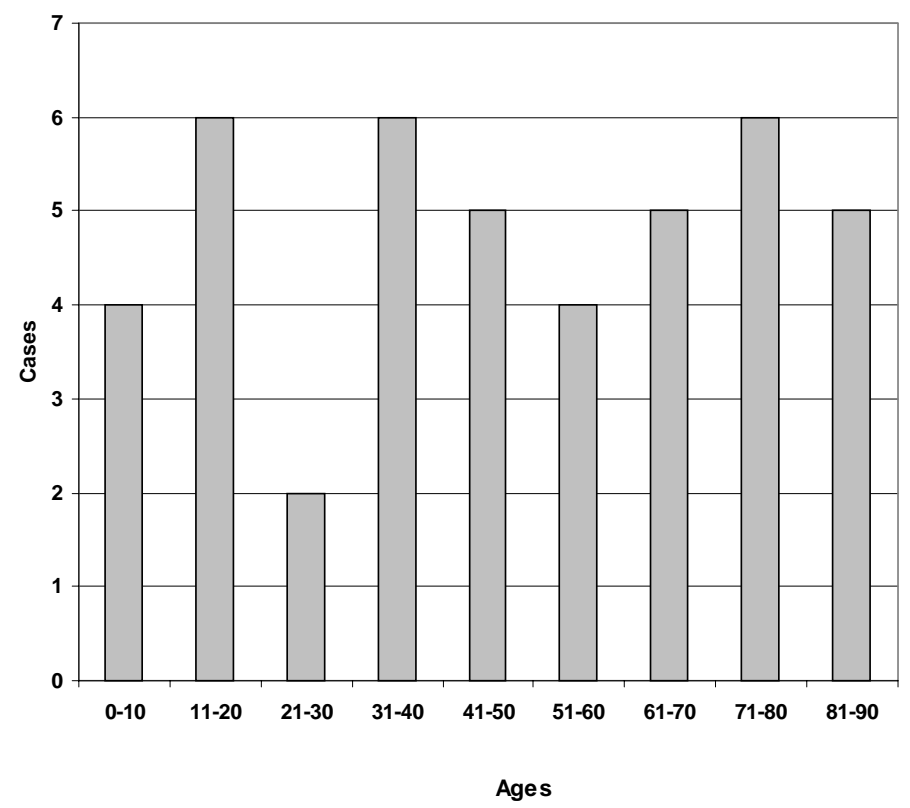

Fig. 1 - Age distribution of 43 patients with scabies.
The follow up revealed two relapses or reinfections produced at about one and a half month after the observation period, which required a new dose of ivermectin.

Drug tolerance was excellent in 32 patients $(84.2 \%$ of the cases studied). In 3 patients a pruritus exacerbation was noted; in another patient there was eczematization of lesions and in two more a mild worsening of associated diseases was observed (psoriasis and porokeratosis respectively).

\section{DISCUSSION}

Oral ivermectin in 2 doses of $200 \mu \mathrm{g} / \mathrm{kg}$, separated by a week interval, showed a good efficacy for treatment of h. s. (cure of $76.34 \%$ of cases) with an excellent tolerance. Its true efficacy, indeed, may be higher since persistence of symptoms (mainly pruritus) in some cases, was apparently due to secondary elements such as eczematization or worsening of concomitant skin diseases (psoriasis, porokeratosis).

Our present results confirm those of MEINKING et al. ${ }^{5}$ who, using a single dose of $200 \mu \mathrm{g} / \mathrm{kg}$ of oral ivermectin, cured 11 patients without other concomitant disease and 8 of 11 more, with associated HIV infection.

Several recent papers ${ }^{1,2,4,6,7}$ agree on the usefulness of the treatment mainly in cases of crusted scabies. Both CORBETT et al. ${ }^{1}$ and HUFFAM \& CURRIE $^{4}$ as well as TAPLIN \& MEINKING ${ }^{7}$ insist on the utility of oral ivermectin, $200 \mu \mathrm{g} / \mathrm{kg}$, (sometimes in repeated doses), together with topical pyrethoids (permethrin 5\%) in treatment of crusted scabies. We share these opinions because our case of severe scabies observed in a HIV seropositive, cured only after using such associated treatment.

Lower doses of oral ivermectin, ex. 100 micrograms $/ \mathrm{kg}$, would not have similar efficacy ${ }^{3}$.

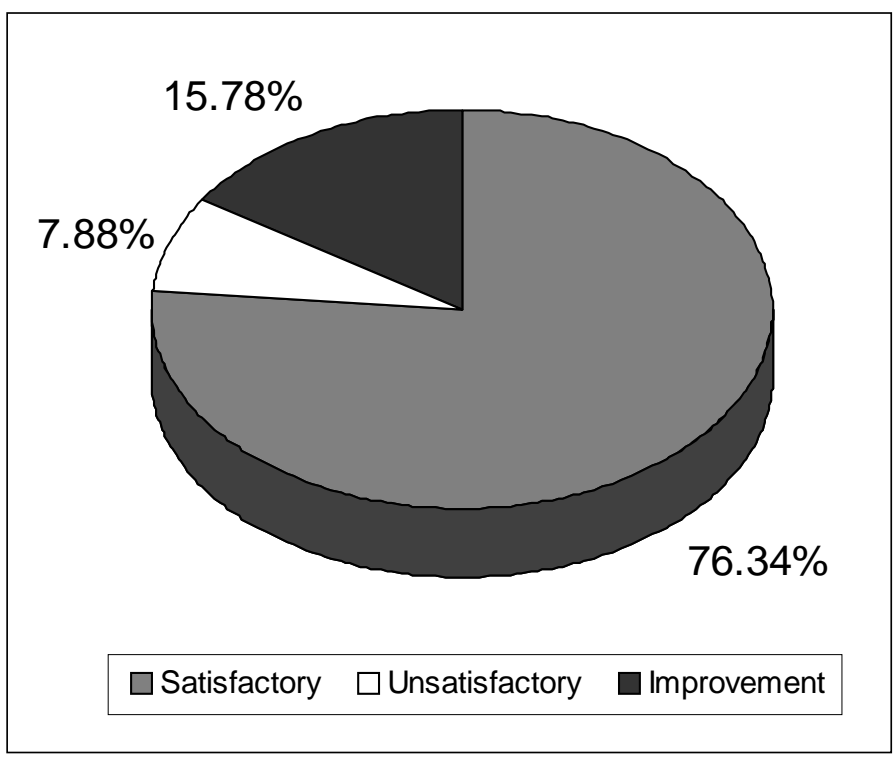

Fig. 2 - Therapeutical results obtained with oral ivermectin $200 \mu \mathrm{g} / \mathrm{kg}$ in human scabies. 


\section{RESUMO}

\section{Tratamento da sarna humana com ivermectina oral}

Neste trabalho foram avaliadas a eficácia e a tolerância da ivermectina oral no tratamento da sarna humana.

A droga foi administrada em duas doses de $200 \mu \mathrm{g} / \mathrm{kg}$ com um intervalo de uma semana entre elas.

Dos 43 casos incluídos no trabalho, só 38 puderam ser avaliados, obtendo-se resultados satisfatórios em 29 pacientes $(76,34 \%)$, melhoria em $6(15,78 \%)$ e insatisfatórios em $3(7,88 \%)$.

A tolerância foi excelente em $84,2 \%$ dos casos analisados.

Os resultados obtidos confirmam a utilidade e a segurança deste fármaco no tratamento da parasitose referida.

\section{ACKNOWLEDGEMENT}

We are grateful to Laboratorios Dispert S.A. Montevideo, Uruguay, which provided the ivermectin, bibliographic references and figures, and to the Medicine School Library, Montevideo, Uruguay, for the bibliographic investigation.

\section{REFERENCES}

1. CORBETT, E.L.; CROSSLEY, I.; HOLTON, J. et al. - Crusted ("Norwegian") scabies in a specialist HIV unit: successful use of ivermectin and failure to prevent nosocomial transmission. Genitourin. Med., 72: 115-117, 1996.

2. DOURMISCHEV, A.L.; SERAFIMOVA, D.K.; DOURMISHEV, L.A. et al. - Crusted scabies of the scalp in dermatomyositis patients: three cases treated with oral ivermectin. Int. J. Derm., 37: 231-234, 1998.

3. GLAZIOU, P.; CARTEL, J.L.; ALZIEU, P. et al. - Comparison of ivermectin and benzyl benzoate for treatment of scabies. Trop. Med. Parasit., 44: 331-332, 1993.

4. HUFFAM, S.E. \& CURRIE, B.J. - Ivermectin for Sarcoptes scabiei hyperinfestation. Int. J. infect. Dis., 2: 152-154, 1998.

5. MEINKING, T.L.; TAPLIN, D.; HERMIDA, J.L.; PARDO, R. \& KERDEL, F.A. -The treatment of scabies with ivermectin. New Engl. J. Med., 333: 26-30, 1995.

6. SULLIVAN, J.R.; WATT, G. \& BARKER, B. - Successful use of ivermectin in the treatment of endemic scabies in a nursing home. Aust. J. Derm., 38: 37-40, 1997.

7. TAPLIN, D. \& MEINKING, T.L. - Treatment of HIV-related scabies with emphasis on the efficacy of ivermectin. Semin. cut. Med. Surg., 16: 235-240, 1997.

8. YOUSSEF, M.Y.M.; SADAKA, H.A.H.; EISSA, M.M. \& ARINY, A.F. - Topical application of ivermectin for human ectoparasites. Amer. J. trop. Med. Hyg., 53 652-653, 1995.

Received: 08 February 1999

Accepted: 16 April 1999 


\section{Revista do Instituto de Medicina Tropical de São Paulo on line.}

Publications from 1997 to the present data are now available on:

http://www.scielo.br/rimtsp

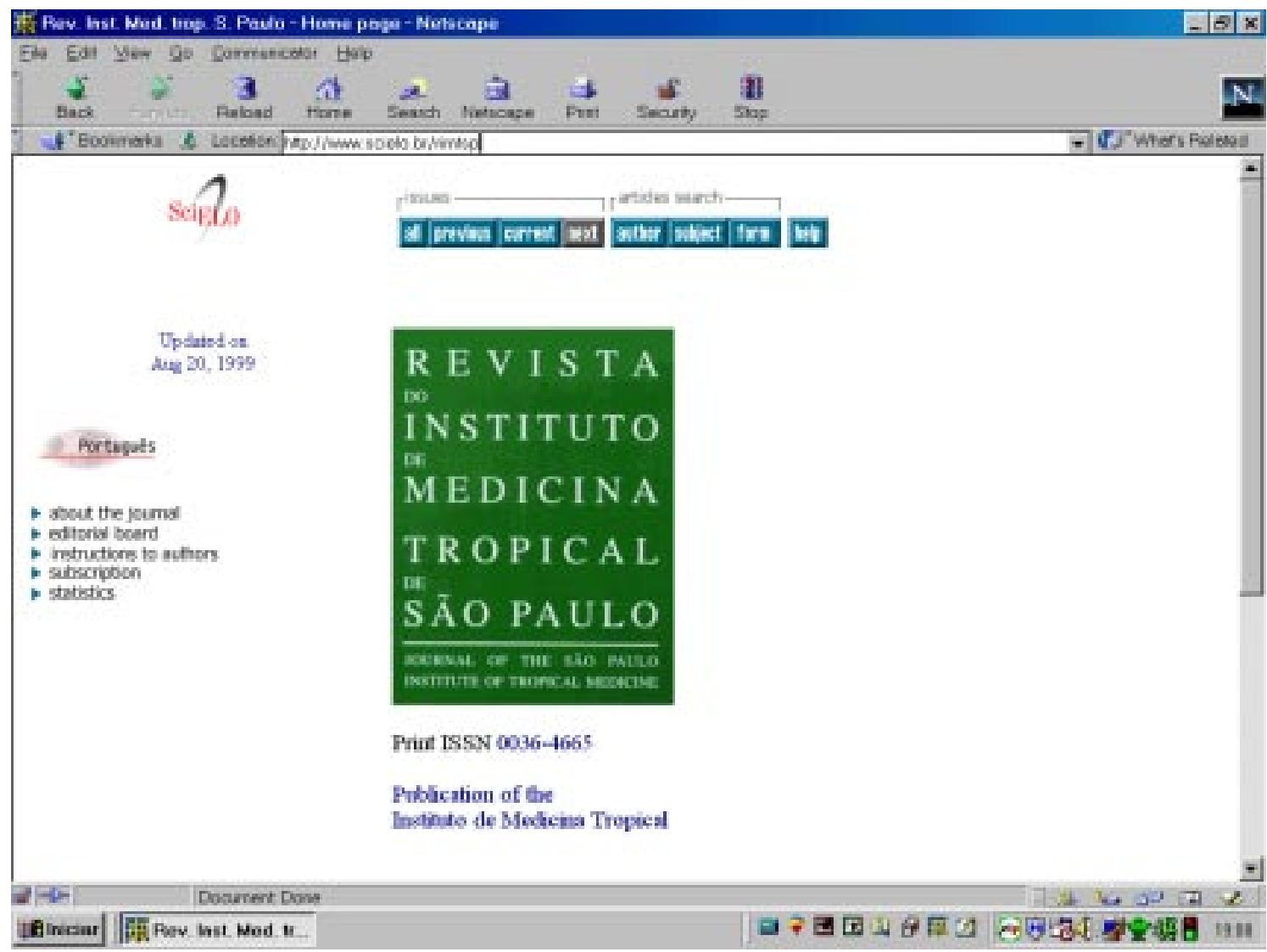

SciELO - The Scientific Electronic Library OnLine - SciELO is an electronic virtual covering a selected collection of Brazilian scientific journals.

The library is an integral part of a project being developed by FAPESP - Fundação de Amparo à Pesquisa do Estado de São Paulo, in partnership with BIREME - the Latin American and Caribbean Center on Health Sciences Information.

SciELO interface provides access to its serials collection via an alphabetic list of titles or a subject index or a search by word of serial titles, publisher names, city of publication and subject.

The interface also provides access to the full text of articles via author index or subject index or a search form on article elements such as author names, words from title, subject and words from full text.

FAPESP/BIREME Project on Scientific Electronic Publications Latin American and Caribbean Center on Health Sciences Information

Rua Botucatu 862 - 04023-901 São Paulo, SP - Brazil

Tel. (011) 576-9863

scielo@bireme.br 